\title{
Creating Creative and Innovative Muslim Society: Bid 'ah as an Approach
}

\author{
Muhammad Mustaqim Mohd Zarif ${ }^{1}$, Mohd Azmir Mohd Nizah², Anita Ismail ${ }^{2} \&$ Adibah Mohamad ${ }^{2}$ \\ ${ }^{1}$ Islamic Science Institute, Universiti Sains Islam Malaysia, Nilai, Malaysia \\ ${ }^{2}$ Centre of Core Studies, Universiti Sains Islam Malaysia, Nilai, Malaysia \\ Correspondence: Muhammad Mustaqim Mohd Zarif, Islamic Science Institute, Universiti Sains Islam Malaysia, \\ Bandar Baru Nilai, 71800 Nilai, Negeri Sembilan, Malaysia. Tel: 60-6-798-6757. E-mail: \\ mustaqim@usim.edu.my
}

Received: April 25, 2013 Accepted: June 28, 2013 Online Published: August 30, 2013

doi:10.5539/ass.v9n11p121 URL: http://dx.doi.org/10.5539/ass.v9n11p121

\begin{abstract}
The objectives of this preliminary work on the Islamic creativity concept are to reassess the role of bid 'ah in creating creative and innovative Muslim through its conceptual and understanding framework; discover the relationship between bid'ah and the advancement of Islamic civilization; and discuss its necessity positively as highlighted in the approach of avoiding extremism or "duna ifrat wa la tafrit" in building a just and balanced Muslim society (ummatan wasatan). By employing the qualitative method through content analysis in evaluating the necessary and relevant reports, articles and texts, it is hoped that this paper will offer a distinctive perspective of bid' $a h$, its positive role and contribution in contemporary Muslim society.
\end{abstract}

Keywords: creativity, innovation, ijtihad, bid' ah, Islam, Muslim

\section{Introduction}

Islam is a religion for all, and it is indeed a global religion. Its historical success as a universal religion and its present status as the fastest growing religion in the world (Doyle, 2011) have certainly made Islam a "mobile idea" due to its simplicity to be understood and its flexibility in meeting the changing demands of the society. There are two concepts that allowed Islam to become a mobile idea, that is bid'ah (innovation) and ijtihad (critical legal thinking) (Umar Faruq, 2006).

Yet for the majority of the Muslims, bid'ah is generally perceived as sinful innovation, which can potentially lead to religious heresy. In many ways, this negative conception of this term is seen as impeding to the creative and innovative aspects of the Muslims. Even the issue of bid'ah as a negative term continues to loom the religious discourse in the present day Muslim society (Saat, 2012). The source of this misconception stems from a prophetic tradition that supposedly condemned any kind of innovation as heretical as will be discussed in details in this paper. In fact, in a recent study, Goddard (2012) has also highlighted the possibility of a conflict between Islam and innovation due to this understanding of bid 'ah.

On the contrary, the concept of ijtihad is often highlighted as the main vehicle that drives creativity and innovation in Islam. The critical and intellectual endeavors undertaken by enthusiastic Muslim scholars and scientists that resulted in the advancement of the Islamic civilization were mostly credited to the rigorous and active implementation of ijtihad, which is legally sanctioned and encouraged by the Islamic Law. Thus ijtihad as a topic has received a great deal of interests from scholars who studied it from various perspectives, especially in its creative role in reform and renewal (Abdullah, Ramli, Jamaludin, Marinsah \& Mohd Nor, 2013; Codd, 1999) and its relation with taqlid or blind following (Khan \& Ramadan, 2011; al-Alwani, 1991; Peters, 1980).

However, the present paper intends to propose a new perspective on the matter. It argues that bid' $a h$ as an important concept in Islam plays a central role, together with the precept of ijtihad, in regulating and stimulating the creative and innovative aspects of Muslims throughout the history. At the same time, the intrinsic link between bid' $a$ h and the Islamic concepts of creativity and innovation is also explicated to highlight the necessity of a proper understanding of bid 'ah and its relationship with the advancement of Islamic civilization in the past. In undertaking this qualitative study, the content analysis method of research is employed, mainly through evaluating the necessary and relevant reports, articles and texts within the proper and actual context of its use 
and application. It is hoped that this preliminary work will not only be able to highlight the necessity of understanding bid'ah in its proper context in building a just and balanced Muslim society (ummatan wasatan), but also offer a distinctive perspective on its positive role and contribution in contemporary Muslim society.

\section{Creativity and Innovation in Islam}

Contemporary Muslim scholars have brought to light the necessity of learning creativity and innovation for the Muslims, which are based on the Islamic perspective. This is because these aspects are not given the appropriate attention by most of the Muslim scholars and authors. Toward a certain extent, several attempts are made to examine creativity and innovation from the Islamic framework, yet only a few of them managed to discuss these issues in a reliable scientific way and at the same time have a sound grasp of these concepts from the Islamic perspective (Al-Karasneh \& Saleh, 2010).

With regard to creativity from the Islamic perspective, it is important to understand the theoretical meaning of this concept and its development. The Arabic dictionaries have defined it simply as "to create something" and "to bring something into being in a way that was not before" (Mustafa, al-Zayyat \& al-Najjar, 1989). It follows from here that creativity means creating something that did not exist before or that has nothing comparable to it. Similar meanings of the term include "to create", "to cause to exist", "to bring into being" and "to originate" can be seen from the American Heritage Dictionary of the English Language (Morris, 1981). Based on these definitions, creativity refers to possessing the ability, capability, capacity and power to create things.

Furthermore, creativity also refers to a situation, attitude or state that shows one's great passion and keen interest in work, goal setting, newness, uniqueness, originality, flexibility, ordinary or extraordinary intelligence and motivation (Goertz, 1991). Yousif (1999) defines creativity as the process of realizing, applying or elaborating the principles and ideals mentioned in the Quran at any time or place, when the act is needed, in order to meet the challenges that arise in the spheres of life. Creativity in Islam, according to him, aims at applying and implementing the Islamic principles to all aspects of life. In this respect, men who are engaged in creativity should ensure that their works or inventions are at all times compatible with the principles and teachings of Islam. Creative thinkers and inventors must also have the sense of responsibility towards the Muslim society in particular and all humanity in general - to bring them to a higher status within their society and to assist them being creative to address future challenges successfully.

Al-Mazeidy (1993) brings a new dimension to the definition of creativity when explaining it as "the ability of designing new forms that are beneficial for humanity and in accordance with the Islamic Law and principles". It can be concluded from this point of view that any newly created things must be useful and beneficial to men. Meanwhile, the creation or invention of any new things must also be in accordance with the Islamic concepts, teachings and principles. Thus, creative Muslims should consider the Islamic Law and follow the divine guidance in transforming their creative idea into a product or service. As such, creative Muslims are then distinguished from the creative non-Muslims in this ethical-spiritual dimension.

As far as creativity in Islam is concerned, it is apparent that Islam is a religion that is conceived by the Muslims to be creative in its nature. Upon its arrival in the Arab society, Islam straight away rejected and abolished the prevailing practices of the Meccans in worshipping God. Its teachings were also regarded as new and alien at that time as they were very different from the religious belief of the pagan Arabs. It came and brought changes to the prevailing customs, traditions and practices that did not respect human rights. It succeeded in changing and transforming a system of belief and culture that was based on blind following of the old generation's heritage into a new system of religion and culture that is based on the divine-guided faculty of reason. It also gives a new meaning for the purpose of the creation of man and links it with his duty as vicegerent on earth (Al-Karasneh $\&$ Saleh, 2010).

Another important creative aspect of Islam can be seen from the divine book it is associated with, that is the Quran. As a book perceived by Muslims to be revealed from God as the final scripture, the Quran contains the basic principles and teachings that constitute the Islamic way of life. At the same time, its verses are regarded as both creative and miraculous in its eloquence, meaning and composition. In fact, the Muslims believe that the verses are inimitable and a sign of divine creativity that is always relevant to all human beings irrespective of time and places (Rahman, 1988).

Similarly, Muhammad as the prophet of Islam has also played an important and creative role in the formation and building of the Muslims society. Through his outstanding moral value, noble character and strategic thinking, Muhammad has succeeded in changing the social and political landscape of Arabia and the Arabs. The introduction of the Madinah Charter upon his arrival in the city of Madinah was one of such examples. Not only that the warring Arab tribes were turned into brothers in the name of the religion, but he also creatively 
inculcated the responsibilities and duties of each members of the newly-established society in building the nation of Islam at the heart of Arabia in the various aspects of religious, political, social and economic life (Nizah, Mohd Zarif, Atoma \& Kandil, 2012).

It was upon the foundation of this new religion, culture and society that knowledge and creativity flourished through the emergence of a myriad of scholars, thinkers, philosophers and scientists exploring various disciplines and sciences (Islam, 2011). In his studies, Akdogan (2008) has succinctly demonstrated the creativity of the Muslims in advancing knowledge, science and producing novel inventions and technologies, which were not only instrumental during the Middle Ages, but also influential in catalyzing the Scientific Revolution which was to be championed by Europe later on.

\section{Bid'ah as an Approach to Foster Creativity and Innovation}

According to Umar Faruq (2006), the Arabic root word bid'ah is derived is connected in its meaning as an outstanding works of human geniuses, especially in arts and literatures. This term is a very well known and commonly quoted term used within the Islamic milieu.

Generally defined as "innovation in religion", it is strictly condemned in the scriptural sources of Islam. In particular, it is reported from Muhammad in an authentic prophetic tradition that "every bid 'ah (innovation) is misguidance, and every misguidance (ends up) in the Hellfire" (Al-Albani, 1991). Taken in its face value, this prophetic tradition seems to condemn any single act of innovation and creative process; Muslims are not encouraged to think and act creatively. In contrast, they should only follow and obey what has been revealed by God and taught by the Prophet. As a matter of fact, this is not the real meaning of the tradition. Yet, due to ignorance and other factors, it has become a popular belief that Islam is rigid, not open to new ideas and Muslims are not encouraged to express creative and novel ideas in fear of being labeled as mubtadi ' or the person who initiated the bid' $a h$.

In fact, by looking at the history of Islam and Muslims that spanned over a thousand years and their success in establishing majestic civilization and remarkable scientific advancement, one would wonder the verity of the negative impact of bid 'ah on the society as a whole. In its literal and linguistic sense, the term is also used in a positive tone as discussed before. Thus, God is also known as the Original Creator (Mubdi $)$ who created the creation and universe out of nothing (Al-Isfahani, n.d.). Similarly, creativity is also coined as al-ibda', and al-tafkir al-ibda ' $i$ simply means creative thinking.

The Muslims, geared by their understanding of the Quran and the prophetic traditions, have expressed their creativity in almost every aspect of life especially that relates to knowledge and science. Even in the aspect of Quranic exegesis, there are a number of creative approaches adopted by the exegetes in explaining the Quran and enrich the understanding of Muslims towards it from different perspectives and according to their respective time and concern. Thus, it is imperative here to ask: What is then the intended meaning of bid'ah that was condemned by Muhammad? How did the Muslims in the past understand it without hampering their creativity? Is there a role for bid 'ah in fostering creativity among the Muslims?

In attempting to answer these questions, it is important to note that undeniably, there is disagreement among Muslim scholars as to the intended meaning of bid'ah mentioned in the tradition. Generally, many of them defined it as "every unprecedented matter or act that is against the traditions (sunnah) of the Prophet, his companions and their followers, and does not have its origins in the Islamic Law" (Al-Jurjani, 1998: 62). Nonetheless, there is disagreement among them on the details and aspects that are included in the term. Equally important is the difference in understanding the term between its literal and technical meanings, which also contributed to the confusion surrounding it.

In one of his works, al-Shatibi (1997) has thoroughly discussed the subject of bid'ah from various perspectives. He affirmed the positive literal meaning of the term as introducing novel and new matter, which was not known before. However, in the religious usage, he also understood it as having a negative connotation as the rest of the Muslim scholars. In addition, he has also included lengthy discussion on the scope and domain of bid'ah mentioned in the tradition. In this regard, most scholars delimit its scope strictly to the domain of worship and rituals ( 'ibadat). In other words, any novel ways introduced relating to worship in terms of the ritual involved and so on without having its origins in the Islamic Law is deemed as bid 'ah. This is because; the religion of Islam has already been perfected with the demise of Muhammad, and as such, any addition to it is condemned as unnecessary and misguided, hence the term bid ' $a h$.

Some scholars also believed that this term includes all aspects of human life; ritualistic and other worldly matters relating to the religion. They argued that since Islam is an all-encompassing religion, there is no single aspect of 
human life that is beyond the grasp of worship. Thus, any worldly matter if made and acknowledged as an act of worship to God without having its basis in the religion will also be categorized as bid'ah. In this regard, there is a common link between these two views as the determinant factor for bid'ah lies in linking it as an act of worship and piety.

However, other Muslim scholar differs in interpreting such term. For instance, al-Qarafi (d. 1285) believed that bid' $a h$ as a term must be further elaborated to avoid confusion. He divided it into five types according to the Islamic legal rules. As such, there is obligatory bid'ah, recommended, permissible, disliked and forbidden depending on the nature and necessity of the act or matter. Interestingly, these five types of bid 'ah mentioned by him are within the domain of worship (Al-Shatibi, 1997: 127). Similarly, al-Shafi'i (d. 820) himself has categorized bid'ah into misguided (dalalah) and commended (hasanah). Anything that transgresses the Quran, prophetic traditions or the consensus of the Muslim scholars (ijma) falls into misguided bid'ah, while anything new that aims to promote nobility and goodness and at the same time does not contradict any of the religious sources is commended bid'ah (Al-Baihaqi, 1999). The differences in interpreting the meaning and scope of bid ' $a h$ and whether it is misguided or commended as presented above became a subject of controversy among the Muslims until the present day. Those who are more literalist and traditionalist in their approach would affirm there is only misguided bid'ah, whereas others would accept a broader interpretation of it from different perspectives.

Regardless, it is imperative to note that as to other aspects of life other than ritual and worship such as inventing a new method or technology of doing things and so on, many Muslim scholars including al-Shatibi (1997: 25) acknowledged that it is outside the scope of bid 'ah mentioned in the prophetic tradition. In fact, it is bid 'ah in its literal sense, which means new and creative invention not known before. As such, Muslims are free to explore and venture into these realms and apply their creativity in improving their productivity and quality of life. This is how the Muslims in the past understood the term and it opened up endless possibilities for them to get creative and produce novel ideas and inventions. In fact, the same stand can also be observed in the present day. In their recent study, Muhamad and Abd Rahman (2004) have focused on the importance of empowering the Muslims through technological innovation. Interestingly, although admitting the negative term of bid 'ah as understood by some, yet they did not see it as an impediment to creativity and innovation.

In this sense, this active and creative process is akin to the concept of ijtihad in Islam. Yet, to exercise ijtihad in the religious domain requires fulfillment of a number of conditions. It is only open to anyone who fulfilled the strict criteria stipulated and the outcome is acknowledged by the religion as valid (Badi \& Tajdin, 2005). Even mistakes or anomalies that emanate from the mujtahid could not be labeled as bid'ah if they are unintentional (Al-Shatibi, 1997: 102). Nonetheless, in matters not relating to rituals, ijtihad tends to be more flexible and less regulatory. In this sense, it only refers to its literal meaning of extension of maximum effort to achieve valuable goal of better world through personal and group expending the fullest effort to achieve a worthy goal of improving the world through personal and group work (Umar Faruq, 2006). Muslims are not only encouraged to exercise ijtihad, but they are also warned against taqlid or blind following that could detriment their intellectual wellbeing. In Islam, there is a limit for ijtihad. Matters relating to God, the metaphysics or the unknown (ghaibiyyat), and the fundamental pillars of the religion are beyond the process of ijtihad.

Similarly, for Muslims, accepting the Quran as the word of God is perennial and requires no ijtihad yet to understand its meanings requires ijtihad, which must be done within the permissible limit. Anyone who contradicts the tenets of the religion and at the same time does not fulfill the criteria of a mujtahid falls into the domain of bid' $a h$ in its religious sense.

To sum up, the term bid'ah in its literal sense connotes the introduction of new and novel ideas not known before. In this regards, it is similar to the concept of ijtihad in Islam as an active, independent and creative process of generating ideas and solutions relating to the religion. Muslims are greatly encouraged to exercise it for their own benefits, like they did in the past, and contribute to humanity in general. In other word, they have to exercise $i b d a$ ' in relation to ijtihad as a positive quality in human being. At the same time, in its religious sense, bid' $a h$ can be understood as a mechanism of controlling the limit and boundary of ijtihad or the creative process. In other word, the Muslims have to be careful in exercising their creativity so as not to transgress the limit and boundary set by the religion, lest they will fall into bid'ah, which is condemned and warned by the prophetic tradition.

\section{The Necessity of Creating Creative and Innovative Muslim Society}

Creative and innovative people are indispensably important in the Muslim society as to foster progress and advancement in various aspects of life. However, creativity and innovation can bring about a mixed reaction 
among people. New ideas that are usually generated from creativity and innovation may not go down well with certain segments of the community who would not simply accept changes. At the same time, those ideas, however, may gain support from their advocates who believe in the need of making Muslim thoughts and practice timeless. The mixed reaction of people towards innovation could be seen from the transformation of education into newly styled ones in the Muslim society in Egypt and Malaya of the $19^{\text {th }}$ and early $20^{\text {th }}$ centuries.

According to Vatikiotis (1980), the $19^{\text {th }}$ century witnessed the waning state of the Ottoman power, which stirred revolutionary movements in several countries including Egypt that was led by Jamal al-Din al-Afghani (1838-1897). Apart from that, the British occupation also generated self-appraisal among the educated Muslims on the weaknesses of the Islamic institutions. Hence, al-Afghani and his disciple, Muhammad 'Abduh (1849-1905), saw the needs for serious reform to suit the challenges of modern realities. The transformation of Islamic education from its focus on the religious knowledge to the integration of religion and the sciences could be regarded as an example of applying creativity and innovation in the educational system of the Muslim society. The principal studies of al-Azhar University; one of the greatest symbols of Islamic institutions for the Muslims around the world, until the middle of $19^{\text {th }}$ century are restricted the learning of the religious sciences only. Then, the shift was made to introduce the non-religious and modern sciences in its curriculum.

Vatikiotis also maintained that 'Abduh's approach differed from al-Afghani in the sense that the former called for educational reform whilst the latter believed in the employment of a political revolution to achieve the intended changes. Rahimin (1997) further asserted that both of them, however, concurred in the significance of education in raising the level of consciousness in Muslims of their own backwardness and the need to make a significant improvement in the educational system to reform and revitalize their lives. The Muslim reformists were generally frustrated with the many weaknesses inherent in the existing educational system at that time. They were not only critical of the existing "dualism" in the educational system, but were also concerned with the lack of moral and religious subjects and the shortcomings of the traditional method inherent in it.

The latter half of the $19^{\text {th }}$ and early $20^{\text {th }}$ centuries saw that the Middle Eastern thinkers' new ideas were diffused in Malaya through its contact with Egypt. In fact, the Malay connection with the Middle East, as demonstrated by Azyumardi (2004), was established back in the $18^{\text {th }}$ century through the likes of scholars such as Muhammad Arshad al-Banjari (1710-1912), Daud al-Fatani (1769-1847) and 'Abd Samad al-Falimbani (1862-1938) who had a close network with several important scholars in Mecca and Egypt. These Malay scholars also functioned as "liaison officers" for other Malay-Indonesian students who came to Mecca and Egypt to study. They were also responsible for spreading Islamic reformism from the Middle East to the Malay World at that time. The spread of new ideas was done through the distribution of books, journals and magazines published in the Middle East. The Malay thinkers at that time also believed that intensive involvement by the press and journalism was also needed to transform the Malay Muslim society into a progressive and dynamic nation. They used the medium of writing to urge the local Muslims to openly accept and embrace the reform and innovation in the educational system. In their reaction, the people in Malaya were divided into two groups; the traditionalists or the Old Faction (Kaum Tua) and the Young Faction (Kaum Muda) or the modernists. The former is strictly opposed to any new ideas, whereas the latter supports new ideas and innovations to advance the society.

The Malay Muslim thinkers published periodicals such as al-Imam (The Leader), al-Ikhwan (The Comrade) and Saudara (The Brotherhood), which propagated progress and development of the Malay Muslims. Al-Imam (1908) admitted itself as an enemy of customs that contradict to Islam, superstitions (khurafat), blind following (taqlid) and innovation ( $\left.\mathrm{bid}^{\prime} a h\right)$. Bid'ah, from the viewpoint of these Muslim thinkers, as mentioned by Hafiz (2005), is "the exact opposite the Sunnah, that is the sayings, practices and living habits of the Prophet". The thinkers also maintained that $b^{\prime} d^{\prime} a h$, either from a linguistic or religious point of view, had no place in the religion. It was a prohibited deviation as warned by several well-known prophetic traditions. Thus, they promoted the suppression of innovation (bid'ah), which to them is confined to the religious practices only because such a deviation had deterred the Malay Muslims from achieving material progress in this world. A sound education, however, could bring changes in their social status.

As such, the $20^{\text {th }}$ century saw the setting up of several newly styled religious educational institutions in Malaya such as Madrasah al-Iqbal in Singapore, Madrasah al-Hadi in Malacca and Madrasah al-Mashoor in Penang. Yet, some of these schools, such as Madrasah al-Iqbal and al-Hadi had to be closed due to the rejection by the local Muslim communities. The teaching of Arabic language together with the religious sciences and English in these reform religious schools was considered as an innovation, which could not be accepted by many people at that time. They perceived English as profane and teaching it together with the religious sciences in a religious school was not in line with their traditional belief of the educational and social norms. 
Today, however, things have changed at least as far as the perception and belief is concerned. Due to the educational reform and efforts in opening up the minds of the people, many Muslims in the present day Malaysia and Indonesia are fairly open in terms of their thinking and perception towards religion and life. Their understanding towards the needs to integrate between the religion and the modern sciences, which was initiated in al-Azhar a century before, has led them to contribute and innovate in propagating a new framework of knowledge and discipline such as the Islamic branding of finance, banking, the halal industry and others and promoting it as emerging trends in the contemporary global scene.

\section{Conclusion}

It is vital for Muslims to have a comprehensive understanding on the sophisticated concept of bid 'ah as a regulatory mechanism for inducing creativity in Islam. It should be sufficiently clear that the concept of bid 'ah as a whole should be viewed to constitute a standard of excellence and not just a blanket condemnation of every unfamiliar practice or new solution introduced by the Muslims in their lives. In fact, the implementation of bid'ah as a creative process started with the advent of Islam and was practiced by Muhammad and the succeeding Muslim scholars, scientists and reformers who had a holistic and balanced understanding of the religion. In fact, it is perhaps justified to state here that the intellectual and social malaise that befell the Muslims was mainly due to their abandonment of the creative intellectual activity in favor of imitation and blind following of custom and authorities, which lead them to ignorance, backwardness and intolerance of innovations and ideas.

\section{Acknowledgements}

The preparation of this paper is made possible through the Exploratory Research Grant Scheme (ERGS) financed by the Ministry of Higher Education Malaysia (Research Code: ERGS/1/2011/SSI/USIM/02/2).

\section{References}

Abdullah, A. B., Ramli, M. A., Jamaludin, M. A., Marinsah, S. A., \& Mohd Nor, M. R. (2013). Postmodernism approach in Islamic jurisprudence (fiqh). Middle East journal of scientific research, 13(1), 33-40.

Akdogan, C. (2008). Science in Islam and the West. Kuala Lumpur: ISTAC, IIUM.

Al-Albani, M. N. D. (1991). Ahkam al-jana'iz wa bida 'iha. Maktabah al-Ma'arif.

Al-Alwani, T. J. (1991). Taqlid and ijtihad. The American journal of Islamic social sciences, 8(1), 129-142.

Al-Baihaqi, A. H. (1999). al-Madkhal ila al-Sunan al-Kubra. Riyadh: Maktabah Adwa' al-Salaf.

Al-Isfahani, H. M. (n. d.). al-Mufradat fi gharib al-Quran. Beirut: Dar al-Ma'rifah.

Al-Jurjani, A. M. (1998). Kitab al-ta 'rifat. Beirut: Dar al-Kitab al-'Arabi.

Al-Karasneh, S. M., \& Saleh, A. M. J. (2010). Islamic perspective of creativity: A model for teachers of social studies as leaders. Paper presented at the Procedia - Social and behavioral sciences, 2(2), 412-426. http://dx.doi.org/10.1016/j.sbspro.2010.03.036

Al-Mazeidy, Z. M. (1993). Muqaddimah fi manhaj al-ibda': ru'yah Islamiyyah. Egypt: Dar al-Wafa'.

Al-Shatibi, I. M. (1997). al-I'tisam. Beirut: Dar Ihya' al-Turath al-‘Arabi.

Azyumardi Azra. (2004). The origins of Islamic reformism in Southeast Asia: Networks in Malay-Indonesian and Middle-Eastern ulama' in the seventeenth and eighteenth centuries. Crows Nest: Allen \& Unwin.

Badi, J., \& Tajdin, M. (2005). Creative thinking: An Islamic perspective. Kuala Lumpur: IIUM Press.

Codd, R. A. (1999). A critical analysis of the role of ijtihad in legal reforms in the Muslim world. Arab law quarterly, 14(2), 112-131. http://dx.doi.org/10.1163/026805599125826354

Goddard, H. (2012). Islam, knowledge and innovation: some basic definitions. In Building a shared future: Islam, knowledge and innovation, 4-5. The British Council's Our Shared Future project and the Centre of Islamic Studies at the University of Cambridge e-book. Retrieved from http://www.cis.cam.ac.uk.

Goertz, M. J. (1991). The relationship of leader's effectiveness and selected traits of creativity. Unpublished Doctoral dissertation, Northern Arizona University.

Zakariya, H. (2005). Islamic reform in Malaya: The contribution of Shaykh Tahir Jalaluddin. Intellectual discourse, 13(1), 49-72.

Islam, A. (2011). The contribution of Muslims to science during the Middle Abbasid Period (750-945). Revelation and science, 1(1), 39-56. 
Khan, L. A., \& Ramadan, H. M. (2011). Contemporary ijtihad: Limits and controversies. Edinburgh: Edinburgh University Press.

Morris, B. A. (2002). The American heritage dictionary of the English language. Boston: Houghton Mifflin.

Muhamad, M. R., \& Abd Rahman, M. N. (2004). Empowering the Muslim ummah through technological innovation. International journal of engineering and technology, 1(2), 152-162.

Mustafa, I., al-Zayyat, A. H., \& al-Najjar, H. A. M. (1989). al-Mu 'jam al-wasit. Istanbul: Dar al-Da'wah.

Nizah, M. A. M., Mohd Zarif, M. M., Atoma, P., \& Kandil, H. (2012). Prophet Muhammad (Pbuh): The savvy politician. Paper presented at the International conference on Islamic leadership-2 (iCiL-2) 2012 proceedings, 97-106.

Peters, R. (1980). Idjtihad and taqlid in $18^{\text {th }}$ and $19^{\text {th }}$ century Islam. Die welt des Islams, 20(3/4), 131-145. http://dx.doi.org/10.2307/1569501

Rahimin, A. A. R. (1997). The reformation of the Islamic educational system: An analysis of the reformist's point of view. Muslim education quarterly, 14(3), 64-72.

Rahman, F. (1988). Translating the Quran. Religion \& literature, 20(1), 23-30.

Saat, N. (2012). Islamising malayness: Ulama discourse and authority in contemporary Malaysia. Contemporary Islam, 6(2), 135-153. http://dx.doi.org/10.1007/s11562-011-0172-9

Umar Faruq, A. (2006). Innovation and creativity in Islam. Nawawi Foundation Papers. Retrieved September 10, 2012, from http://www.nawawi.org/

Vatikiotis, P. J. (1980). The history of Egypt from Muhammad Ali to Sadat. London: Weidenfeld and Nicolson.

Yousif, W. (1999). Creativity in Islamic thought: A comparative analysis. Unpublished Master thesis, International Islamic University Malaysia.

\section{Copyrights}

Copyright for this article is retained by the author(s), with first publication rights granted to the journal.

This is an open-access article distributed under the terms and conditions of the Creative Commons Attribution license (http://creativecommons.org/licenses/by/3.0/). 